\title{
The Effectiveness of NUL Programmes in Creating the Social Responsibility
}

\author{
'Malimpho Elsie Seotsanyana' \\ ${ }^{1}$ Department of Language and Social Education, National University of Lesotho, Lesotho \\ Correspondence: 'Malimpho Elsie Seotsanyana, Department of Langauge and Social Education, National \\ University of Lesotho, Lesotho. Address: P.O. Roma 180, Fax: 266-2234-0000. Orcid no. 0000-0001-7914-5365. \\ E-mail: mseotsanyana@yahoo.co.uk
}

Received: July 17, 2020; Accepted: August 28, 2020; Published: September 1, 2020

\begin{abstract}
The employer's views have been sought on the quality of the National University of Lesotho (NUL) programmes in relation to addressing the concept of social responsibility. The employers' views were sought through observing the quality of performance of the NUL graduates at the workplace and at the community engagements. The NUL designed programmes that are expected to address the societal needs, hence the reason why it is important to find out whether the programmes that prepared the graduates for the workplace have a successful outcome.

A total of 150 employers in the Lesotho Ministries of Education and Training as well as Local Government and chieftainship in three of the ten districts of Lesotho formed the sample of the study. A two part questionnaire with four point likert scale of strongly agree and strongly disagree; highly satisfied and highly dissatisfied was designed to find out information on the employers' perceptions on the performance of the NUL graduates in relation to social responsibility. Frequency counts analysis with descriptive statistics was employed to indicate the results of the study. Research results confirmed that the NUL programmes have deficiencies in moulding all graduates with competence in social responsibility. It was observed that there were graduates that have achieved the social responsibility skills, but there are those graduates who still require further training on the issue of social responsibility. It is therefore recommended that the NUL should periodically review its programmes in order to prepare a well rounded graduate that could be a community developer.
\end{abstract}

Keywords: The National University of Lesotho (NUL), social responsibility, employers' perceptions, work place, Ministries of Education and Training and Local Government and Chieftainship

\section{Introduction}

Several studies, worldwide, have been conducted on higher education and social responsibility. This is to find out whether universities have adopted and integrated social responsibility issues to fulfil the needs of the societies. According to UNESCO document of 1995, higher education institutions are to address societal needs and produce graduates with a sense of civic responsibility who could apply the theory of their disciplines to local government issues. Specifically in the UNESCO document it is stated that the "aim should be to make higher education more responsive to the general problems facing humanity and needs of economic and cultural life and more relevant in the context of specific problems of a given region, country or community" (UNESCO, 1995, p. 21).

The idea that higher education institutions should show social responsibility to humanity was emphasised in the 1996 UNESCO declaration on higher education and social responsibility. In this declaration, it was stated that "higher education solely for personal development cannot be considered acceptable nowadays" (1996 UNESCO declaration in Ratto and Giufre, 2014, p. 232). But the "intellectual advancement of individual must be related also with the broader goals of sustainable development, poverty reduction poverty, peace and human rights" (Giuffre and Ratto, 2014, p. 232). As it seems one of the characteristics of higher education institutions is to "play a crucial role in creating knowledge societies" Ibid (p. 232) that would be involved in the development of their own communities.

In 2005, Higher education institutions worldwide formed the Talloires network at Tufts, in France. This was the foundation of an international alliance specifically garnered to understand the social role of the universities. (www.tufts.edu.talloiresnetwork). The Talloires network grew up to 200 universities in membership worldwide. Its focus was on the promotion of civic roles and social responsibility of their member institutions as well as to deepen engagement with local and global communities (Weiss, 2016). And further indicates that "more and more 
universities in the world are integrating social responsibility into their mission statements, including their research and teaching missions, arguing that higher education is better off when it gives back to the society that is responsible for funding it" and members of Talloires network rose up to 363 in 77 countries in 2016 (Weiss, 2016: unnumbered)

The National University of Lesotho (NUL) is no exception to this issue. If the NUL has to instil social responsibility in its graduates, it must face up to change. It has to structure the learning environment to suit the analysis and action needed to build a healthy society. In other words, does the NUL in its programmes expose and provide its graduates with the information on social responsibility and practice? How are the programmes organised to meet the challenges of civic engagement and social responsibility? And is the NUL responsible for the social well being of the citizens?

It is therefore the core business of this study to explore the key issues facing the NUL in the $21^{\text {st }}$ century specifically on the theme of social commitment. The employers from the government ministries were the major source of information and by no means the only external stakeholders that can give their perceptions of NUL graduates and the impact of academic institution on social responsibility. The employers can further explain the link between the corporate vision and graduates educational background.

\section{Literature Review and Social Responsibility}

According to Bokhari (2017), social responsibility can be used interchangeably with other concepts such as social responsiveness, social performance, social responsible business, and corporate social responsibility, just to mention a few. In this study, social responsibility will be used more often than other related terms, not withstanding that other terms are not important. In that way, Social responsibility will be addressed in the context of a university - University Social Responsibility (USR). There are many definitions of social responsibility. One of them is that a university educates "participative citizens and become involved in civic activities related to the communities in which it operates and on international level" (Wigmore - Alvarez and Ruiz - Lozano, 2012, p. 480). In the same manner, Mohamed (2015: 2394) defines University social responsibility as "the accountability of establishing and maintaining an ethical approach of the management of university's internal and external stakeholders, strengthening societal citizenship and commitment to society and providing services to local community..." The reports written by the University of Cape Town (2004) on social responsiveness explain social responsiveness as a promising tool that addresses challenges of a better society and broaden social responsibility issues (Favish, 2005). According to these above mentioned definitions, there is a rationale to talk about university social responsibility in a country. With this understanding, it is often assumed that there are several issues that require social responsibility such as high social inequalities, unemployment, illiteracy, highly skilled labour force, drug and alcohol abuse, HIV/AIDS, crime, homelessness and poverty. In this case Lesotho, like other countries expects and calls for new responsible actors who are the National University of Lesotho graduates. The graduates are the responsible actors that could curb the existing community and national problems and create a better society with little or no problems in the $21^{\text {st }}$ century arena.

But in this study, the concept university social responsibility will be emphasised. It defines the role of the universities in the development of a society. Clark (2004:1) is aware of the role of universities and social responsibility According to him:

\section{Universities around the world found themselves under increasing pressure to change the way they operate. Alert universities gradually recognised that they had to respond to profile rating new demands of government; industry, societal groups, while maintaining and improving their traditional field of research, teaching and student learning that become more complicated with every passing year.}

The National University of Lesotho, with its programmes it is argued, need to be aware of the world wide context of change. The vital role is to produce graduates who are capable of facing transitions, and under pressure to respond to changing national needs with shrinking national resources. They should also be capable of reflecting change assumptions about human development. It is indeed that the NUL is expected to quickly adapt and develop programmes of service to meet the rapidly changing customer expectations. In short, the NUL is "expected to spearhead the production of skilled manpower required to manage both public and private sectors" (Ayaya, 1997, p. 1) in order to build a healthy society. The issue of healthy society is also mentioned by Favish (2005) in his research. She found out that the importance of higher education institution is to "produce graduates who are capable of critical and creative thinking and who can also contribute to economic needs, meet diverse social needs and build vibrant civil society and consolidate democracy" page 2 of 4 . 
It is worth pointing out that growing discontent with the education system in a time of rising unemployment is not new. The type of education offered at the NUL has attracted numerous complaints from employers .Employers felt that school standards in basic skills were very low. There is a concern to make education more relevant to employment and the needs of the industry. Several people informally, over the air, and in news papers have a concern for the standards and criticism of the poor relationship between NUL and industry. One question asked is the very function of schooling suggesting that NUL does not provide the necessary skills.

According to Jongbloed, Enders, and Salerno (2008), one of the key missions of Higher Education Institutions (HEI) is to become an instrument of change that provides necessary skills to the youth to make them adaptive, adaptable and transformative in order to reduce the rate of unemployment. It means that HEI should expand its activities beyond the mission of teaching and research. Probably it has to include lessons on service learning in order to serve the communities where they are situated. To them, the understanding is HEI should take into consideration the importance of partnership with surrounding communities and stakeholders. However, Wigmore - Alvarez and Ruiz - Lazano (2012) emphasise the need for universities to embark on research studies in the societies in order to get their needs. Such needs would be a guide towards the accomplishment of university social responsibility. In their words:

$$
\begin{aligned}
& \text { The universities should be capable of assessing the needs of society as a whole } \\
& \text { And providing a solution for its problems in addition to contributing to its well } \\
& \text { being and social and human development ... The University should educate } \\
& \text { participative citizens and become involved in civic activities related to the } \\
& \text { communities in which it operates and on international level p } 480 .
\end{aligned}
$$

The very function of the University learning, as it seems, is about knowledge and skills. Acquiring knowledge and skills in turn "promote socially responsible citizens" (wigmore - Alvarez and Ruiz - Lazano, 2012: 481) and be fully involved in the socio - economic development of their communities. As it seems universities are expected to give graduates learning abilities that make them adjust to new market changes and new technology and be much more for the society in solving their social and economic problems. In short, universities should provide learning that gives them abilities to solve problems. In conclusion, the understanding is that higher education institution should educate future citizens that would be more responsive to general problems of humanity. This being the case how is the NUL graduate in relation to solving the problems of humanity? A few examples of how universities address social responsibility can be read in the paragraphs that follow.

\subsection{The Case Studies about University Social Responsibility}

The literature comprises studies that have explored different ways that universities have integrated and implemented social responsibility in their curriculum and activities. For instance; Mohamed (2015) conducted an inquiry with twelve (12) vice deans from South Valley University (SVU) in Egypt. Mohammed (2015) indicates that the objective of the study was to find out whether there was an integration of social responsibility in the university activities such as: "vision, mission, values, goals and management systems; policies and provision of actions, evaluation of services; and development of social collaboration with stakeholders..." p 2400. Themes that emerged from the research are that SVU seemed to have received and integrated social responsibility activities. But, it had policies that lacked appropriate structure as well as specific budget to call on board all university stakeholders to participate. Further research was recommended in order to develop university social responsibility frame work that would work for all universities in Egypt.

In a study of Dahan and Senol (2012), the inquiry was to find out whether University of Instabul Bilgi, Turkey has been successful in integrating social responsibility in its activities. Information was gathered through in depth interviews with two secretary generals of the university research centres. Additionally a deeper analysis of university documents such as students' handbook, reports, unpublished reports, University evaluation reports, community outreach surveys, University research centres and action plans were viewed and analysed. The report indicated that Instabul Bilgi University had several social responsibility activities and several courses designed around social responsibility subject (Dahan and Senol, 2012). Therefore, the success of the Istanbul Bilgi University is said to be through:

The role of management's involvement and willingness in supporting and implementing social responsibility actions. In general management involvement and interest is an important signal to faculty, staff, students, alumni, and other stakeholders that the institution's citizenship engagement is an operational priority (Dahan and Senol, 2012: 102). 
It is at the Instabul Bilgi University that social responsibility activities and several courses were designed such as "free educational lessons given to high school graduates - first level English and computing, computer accounting, community outreach programmes, educational supportive activities for women and children and youth who live under severe social discrimination and poverty and business ethics" (Dahan and Senol, 2012, p. 101). It is concluded that though the University has commitment on the academic activities, but it also seems to concentrate its efforts on community engagement activities that are beneficial to the community at large.

In Jerusalem, at the Hebrew University Faculty of Law, the status of social responsibility and implementation was explored. The outcome was that social responsibility in a form of community service is highly practised (case studies presentation at the Taillores, 2005 conference) "some community engagement is part of the formal curriculum." According the Hebrew University presentations of 2005 and 2018 at the Taillores conferences, There is a unit of social involvement with a social involvement committee where Faculty members and staff are involved in preparing graduates in four leadership programmes namely: social leadership, Arab - Jewish leadership, women leadership and educational leadership.

Furthermore, the Hebrew University has other activities such as university students provide high school students with knowledge and skills on handling the matriculation examination. The high school students are also guided on the selection of relevant university courses. In each curriculum, as indicated, the Hebrew University integrates four hours of community engagements such as in the dental health and nutrition where participation is said to be mandatory (Case studies presentation at the 2005 Taillores conference).

And lastly, the Hong Kong Polytechnic University has developed an alliance with the community. A motto that cherishes social responsibility is "to learn and to apply for the benefit of mankind" (Tong, 2017: unpaged). This means the University has reviewed its programmes to incorporate the elements of community engagements. As it seems, the Hong Kong Polytechnic University has research as the integral part of academic life that helps them serve the needs of the society. In conclusion, the idea of social responsibility in universities is twofold. There are universities that are active in promoting social responsibility in the teaching and learning. At the same time, there are those that have an idea of the concept but are not so active in fulfilling its needs.

\subsection{Research Questions}

Two research questions that were addressed in this study are as follows:

1. Do NUL graduates in employers' supervision show knowledge and practice on the concept of social responsibility?

2. What relevant features do employers detect that show incorporation of social responsibility knowledge as far as community engagement is concerned?

\section{Methodology}

\subsection{Research Design}

This is an employer survey that adopted the qualitative paradigm, though certain data was analysed quantitatively through descriptive statistics of frequency counts and percentages.

The focus was on two ministries: the Ministry of Education and Training, Local Government and chieftainship. The key issue of selecting the two ministries was that they have the highest number of employer constituencies, and have employed a large number of NUL graduates as these are the biggest ministries.. Additionally the two ministries are fully involved in the activities of community engagement and development. They both serve people even at the nation's grass roots in the rural areas. Hence the NUL graduates' knowledge and practice of social responsibility could be easily detected.

In each of the ministries, a total of seventy five (75) employers were purposively selected. It should be clear that only those employers that had NUL graduates in their departments were subjected to selection. Therefore, a total of one hundred and fifty employers formed the total sample of the study. In the Ministry of Education and Training, the following formed the set of employers: the head teachers, deputy head teachers, and heads of departments in schools as well as the Ministry of Education and Training officers : curriculum officers, education inspectors, and chief education officers.. While in the Ministry of Local Government, heads of divisions, human resource directors, and immediate supervisors were consulted.

The information on the employers' perceptions was sought through the use of a questionnaire. This employer questionnaire was divided into two parts namely; the first part was on the rating items specific for employment practice, while the second part was on community engagements. On the first part of the questionnaire that described employment practice, items were designed and rated on the 4 point likert scale type of strongly disagree, disagree, 
agree and strongly agree. And the second part of the questionnaire on community engagements, items was also rated on the four point likert scale of highly satisfactory, satisfactory, unsatisfactory, and highly unsatisfactory.

Several questions on the employer and community engagements questionnaire were adopted from the inventory tool for higher education civic engagement. This is a tool that Watson (2004) developed. It was designed for the Association of Commonwealth Universities to explore the involvement of universities in imparting social responsiveness concept to the students. Of the 30 items from this tool that were rated, only 12 were adopted for use to assess the National University of Lesotho graduates. The selected items are shown in the analysis section under research question one and two in the forth coming paragraphs. Furthermore, the questions were developed to seek information on the graduates' knowledge and understanding of social responsibility activities.

The self-administered questionnaire was distributed to 150 employers at their work places in the Ministry of Education and Training and Local Government and Chieftainship. Each respondent was given a maximum of five days to read and complete the questionnaire. Where there was a possibility of an immediate response, it was preferably accepted. It was not easy to collect a hundred percent response. At later days after examining the data, further classifications of the responses were requested. On this occasion, three districts were selected e.g. Mohale's Hoek, Butha-Buthe and Maseru. These are the districts that were used in the previous study on the evaluation of NUL programmes using the graduates' views. The results found in the three districts were put together to get the analysis and conclusions on the issue of social responsibility.

Two groups of employers, 20 in a group, were randomly selected to respond to the pilot study. This was to find out if the instrument to be used is valid and reliable in order to yield successful results. The first group responded to the pilot test and the results were analysed. A further pilot study was undertaken with the second group in order to find out if the results of the second group would yield similar or different to those of the first group. The two pilot test results seemed similar. Therefore, it could be concluded that the instrument, if used properly, would give valid and reliable results. Several researchers, such as Sekaran and Bougie (2013) emphasise the importance of content validity and stability measures in research studies, and they say with the consideration of validity and reliability, results become consistent.

\subsection{Analysis of Data}

In responding to two research questions on page 5 that read: do NUL graduates in employer's supervision show knowledge and practice on the concept of social responsibility? and what relevant features do employers detect that show incorporation of social responsibility knowledge and practice as far as community engagements are concerned? Frequency of response analysis was adopted. According to Maliyamkono (1982, p. 11), frequency of response analysis is a simple technique which is useful for accumulating data on specific topics. It might be vital to know the percentages of employers in two ministries combined. It may also be useful for examining the perceptions of different employers on what impact has the NUL curricula given to its graduates on social responsibility. In general, frequency response analysis is useful for providing a summary of information contained in the questionnaire.

\section{Ethical Consideration}

The ethical consideration was also considered when involving participants in the study. This was to make them feel free to respond to the research items. First, a memorandum was written and distributed to the employers that had been selected to be in the study. In the memorandum the nature of the research was introduced, permission to undertake research study was also requested. Second, employers were asked to participate in the research study. In the memorandum, participants were also given freedom to accept or decline the request. Last, employers were asked to give the information about the research study to the NUL graduates employed in their institutions because they are at the centre of information.

\section{The Findings}

The analysis in this research study was done in accordance with the research questions as stipulated in page (5). The first research question reads as thus:

\subsection{Research Question 1}

Do NUL graduates in your supervision show knowledge and practice on the concept of social responsibility?

In order to get information on the above mentioned research question, 6 items were selected and rated on a scale of strongly disagree as (1) to strongly agree as (4). The items that got rated are as follows: graduates' desire to achieve, effective communication, graduates' willingness to learn and continue learning, respect for management 
and taking orders, use of theory into practice, and attainment of service learning. The items are presented from table 1 and 2 showing frequency counts.

Table 1. Items related to administrative issues in the ministries

\begin{tabular}{|c|c|c|c|}
\hline & $\begin{array}{l}\text { NUL graduates desire to } \\
\text { achieve }\end{array}$ & $\begin{array}{l}\text { Graduates' } \\
\text { communication }\end{array}$ & $\begin{array}{l}\text { Graduates willingness to } \\
\text { learn and continue learning }\end{array}$ \\
\hline Ratings & Frequency and percentages & Frequency and percentages & Frequency and percentages \\
\hline Strongly disagree & $17(11.3 \%)$ & $10(6.8 \%)$ & $7(4.7 \%)$ \\
\hline Disagree & $26(17.3 \%)$ & $32(21.9 \%)$ & $29(19.5 \%)$ \\
\hline Agree & $89(59.3 \%)$ & $83(56.8 \%)$ & $81(54.4 \%)$ \\
\hline Strongly agree & $18(12.0 \%)$ & $21(14.4 \%)$ & $32(21.5 \%)$ \\
\hline TOTAL & $150(100 \%)$ & $146(100 \%)$ & $149(100 \%)$ \\
\hline
\end{tabular}

Note: Tables in this paper may not add up to a total of 150 participants since the analysis focused on the available responses.

\subsubsection{NUL Graduates' Desire to Achieve}

Table 1 reveals that employers' ratings on NUL graduates' desire to achieve vary. For example, some employers rated NUL graduates positively $(12 \%)$ and $(59.3 \%)$ on strongly agree and agree respectively with the idea that NUL graduates have the desire to achieve, while $17.3 \%$ on disagreed and $11.3 \%$ of the respondents strongly disagreed. Though a large percentage of respondents agree with the item on the desire to achieve, there is still a significant cumulative percentage of (28.6) that indicates that NUL graduates do not have the enthusiasm to achieve. At this point, one may argue that perceptions about desire to achieve may depend on the individual frame of reference. That is, one cannot really know if the desire to achieve has been perceived similarly by all respondents. Probably there is need to get further perceptions from those employers that have a contrary response to the desire to achieve.

\subsubsection{NUL Graduates' Effective Communication}

The NUL graduates effectively communicate their ideas as shown by $(71.2 \%)$ on agree and strongly agree. On other hand, $(28.7 \%)$ of the respondents seemed to disagree with the fact that NUL graduates can effectively communicate ideas at work. From the respondents' perspectives, one important aspect could be deduced here that, despite the shortcomings of some of the graduates on the issue of effective communication, a large number of graduates communicate well. However, there is still need to improve the university education on effective communication in order to achieve greater success.

\subsubsection{NUL Graduates' Willingness to Learn and Continue Learning}

The employers' opinions seem to differ in regard to willingness to learn and continue learning. The (4.7\%) and $(19.3 \%)$ strongly disagree and disagree respectively that NUL graduates have the willingness to learn and continue learning. On the other hand, (54\%) and (23.3\%) positively agree and strongly agree with the issue. If (24\% ) of the graduates still have problems in long life learning of issues at work, it seems quite appropriate to pay attention to and review the programmes of study to enhance the capacity of graduates to perform duties effectively. One would assume that there are graduates that have not been exposed enough to the idea of continuous learning even after university training. At this juncture, much has to be done by the University to create a programme that would work as a strategy to connect university teaching and the world of work.

Table 2 below still follows the trend whether graduates cope with activities of the work place. The items that were rated on a four point likert scale are: respect for management and taking orders, use of theory into practice, and attainment of service learning as shown in the table.

Table 2. Further expansion on the administrative duties in the ministries

\begin{tabular}{lllll}
\hline & $\begin{array}{l}\text { Respect for management and taking } \\
\text { orders }\end{array}$ & $\begin{array}{l}\text { Use of theory into } \\
\text { practice }\end{array}$ & $\begin{array}{l}\text { Attainment of service } \\
\text { delivery }\end{array}$ & \\
\hline $\begin{array}{l}\text { Ratings } \\
\text { Strongly }\end{array}$ & $6(4.1 \%)$ & $8(5.6 \%)$ & $11(7.6 \%)$ & \\
disagree & & & &
\end{tabular}




\begin{tabular}{llll} 
Disagree & $36(24.0 \%)$ & $30(21.0 \%)$ & $27(18.6 \%)$ \\
Strongly agree & $86(57.3 \%)$ & $86(60.1 \%)$ & $87(60 \%)$ \\
Agree & $18(12.0 \%)$ & $19(13.3 \%)$ & $20(13.8 \%)$ \\
TOTAL & $146(100 \%)$ & $143(100 \%)$ & $145(100 \%)$ \\
\hline
\end{tabular}

\subsubsection{Respect for Management and Take Orders}

Although the employers differ in opinion as far as respect of management and taking orders is concerned, NUL has exposed the majority of the graduates to the importance of respect for management and taking orders. For instance, 69.3 percent combined (on $12 \%$ strongly agree and 57\% agree respectively) have scored positively on the issue. Moreover, the fact that the majority of employers applaud NUL most graduates on the understanding of the administrative issues shows that graduates have been exposed to the rationale of the corporate administration and activities. For the graduates who failed to understand the rationale of respecting management and taking orders: $28 \%$ combined on ( $4 \%$ strongly disagreed and $24 \%$ disagreed) may result from two issues. First, it may be through the problem of the learning principles. That is, how one correlates the acquired learning and skills appropriate to the workplace. Second, it also depends on individual's character and willingness to learn. It means such graduates did not have the opportunity to practice/assimilate various strategies in relation to workplace administrative issues while still training. As it seems, NUL programmes, if they prepare graduates to succeed in the workplace, should carry an element of work place expectations in them as a way of exposing the graduates to all workplace activities.

\subsubsection{Use of Theory to Practice}

The research results in this table determine that there is a significant number of employers that translate that university teaching and learning is beneficial to graduates as far as use of theory to practice is concerned. A cumulative analysis of $(73.4 \%)$ on agree and strongly agree shows that a high proportion of respondents confirmed that NUL graduates actually use theory they have learned to help them cope with practice at the workplace. It gives an idea that theoretical knowledge and skills acquired through their four year schooling facilitates effectiveness at the workplace in production and communication. The idea of theory into acquisition of skills is translated by Jongbloed, Enders, and Salerno (2008)'s writings that students should be equipped with the basic skills at the training in order to do the job well. However, $(25.3 \%)$ has actually declined that they disagree and strongly disagree with the fact that NUL graduates use theory to help them acquire the workplace practices. The $(25 \%)$ on disagree and strongly requires NUL to popularize the translation theory into practice as far as work preparation is concerned. This might give them office work and community engagements aspects.

\subsubsection{Attainment of Service Learning}

0n graduates' attainment of service learning highlights the differences in opinion among the respondents. Attainment of service learning has been scored high (73.8\%) on agree and strongly agree. The respondents seem contend with the way NUL graduates have been prepared to do proper service at the work place. On the other hand, a total of $26.2 \%$ did not agree that NUL equips its graduates with appropriate and proper skills of service learning. Comparing the two responses, it is revealed that learning might have been perceived differently by graduates. In the process of learning it seems, there were those students who considered classroom content to prepare them for the place of work. There were also those who never connected the classroom teaching and learning with activities at the workplace. The fault here lies with the National University of Lesotho. Although, a high percentage of graduates seem to have attained high standard of competence as expected on service learning. But there is a number that does not excel in service learning. This indicates that studies should be carried out in order to explore factors which might be detrimental to preparing students for service learning.

\subsection{Research Question 2}

Tables 3 and 4 that follow give an analysis of the collected data on research question two that says: What relevant features do employers detect that show incorporation of social responsibility as far as community engagement is concerned?

Table 3. Ratings on Community engagements

\begin{tabular}{llll}
\hline & $\begin{array}{l}\text { NUL graduates } \\
\text { participation in community } \\
\text { projects }\end{array}$ & $\begin{array}{l}\text { Graduates relationship with } \\
\text { members of the community }\end{array}$ & $\begin{array}{l}\text { Graduate } \\
\text { activities among } \\
\text { community }\end{array}$ \\
\hline Ratings & Frequency and percentages & Frequency and percentages & Frequency and percentages
\end{tabular}




\begin{tabular}{llll} 
Highly & $23(15.6 \%)$ & $20(13.7 \%)$ & $23(15.6 \%)$ \\
satisfactory & & $79(54.1 \%)$ & $54(36.7 \%)$ \\
Satisfactory & $63(42.9 \%)$ & $41(28.1 \%)$ & $61(41.5 \%)$ \\
Unsatisfactory & $50(34.0 \%)$ & $6(4.1 \%)$ & $9(6.1 \%)$ \\
$\begin{array}{l}\text { Highly } \\
\text { unsatisfactory }\end{array}$ & $11(7.5 \%)$ & $146(100 \%)$ & $147(100 \%)$ \\
TOTAL & $147(100 \%)$ & & \\
\hline
\end{tabular}

\subsubsection{Participation in Community Projects}

The evidence in Table 3 suggests that the NUL programmes have an impact on the graduates. That is, $58.5 \%$ (on highly satisfactory and satisfactory combined) of the respondents indicate satisfaction towards NUL graduates' participation in community projects. Employers are aware of programmes' activities and that the programmes have contributed significantly to the graduates, not only in the classroom, but also socially and otherwise. It looks like the programmes have enabled the graduates to see themselves as having the necessary abilities to participate meaningfully in community projects. However, a total of (41.5\%) respondents did not view the NUL programmes as having effective instruction as far as participation in community development is concerned. A question that could be asked is that: how can NUL programmes be said to be good in preparing graduates in participating in community development when $41.5 \%$ (on both highly unsatisfactory and unsatisfactory) still lack skills towards social commitment. At this point one may assume that effort has to taken in the programme activities to increase the number of graduates that would contribute significantly to community participation if the intention of the country is geared towards development.

\subsubsection{Relationship with Members of the Community}

In comparison, employer analysis indicates highly satisfaction and satisfaction of the NUL graduates' relationship with members of the community. This is rated by $(67.8 \%)$ of the respondents. It is also evident from the employers' ratings that there is some dissatisfaction and highly dissatisfaction (32.2\%) with the way NUL programmes do not prepare graduates to interact with the community. The reluctance to interact with the community could be that graduates at the preparation did not acquire knowledge, skills and understanding in general community involvement and commitment.

\subsubsection{Volunteer Activities among the Community}

Two aspects are raised up in this table. First, employers (53.3\%) rate NUL graduates as people who value volunteering activities among the community. This is a way of showing the commitment to duty of the graduates. Second, a slightly lesser percentage (46.7) considers NUL graduates inability to volunteer activities among the community. It turns out once again that NUL programmes have both significant positive and significant negative effect as far as community engagement is concerned. Though there is a higher percentage of graduates with skills positive and understanding of community engagements, but the fact that (46.7\%) have no interest in community problems and slightly displays less commitment to community engagements. Probably the university seems to stress academic learning and ignores the learning for practice. Perhaps this may be the reason they are unable to volunteer work with the community. According to Tong (2017), working with the community is an important issue that deserves an attention. One recommendation is that NUL needs to modify and refine its programmes in order to produce effective and competent graduates who could appreciate to volunteer work with the community. Also, there is need for the University to have a written policy in the initial students' preparation in line with community engagement.

Table 4 is a continuation of employers' perceptions of NUL graduates' involvement in community engagement. This is rated on the following items: NUL graduates interest in work community cooperation, graduates awareness of the changing institutional needs and sharing resources and graduates always active in the work that serves the nation.

Table 4. Further ratings on community engagements

\begin{tabular}{lllllll}
\hline & $\begin{array}{l}\text { Interest in } \\
\text { community } \\
\text { cooperation }\end{array}$ & & work & $\begin{array}{l}\text { Awareness of the changing } \\
\text { institutional needs and shrinking active in the } \\
\text { national resources }\end{array}$ & $\begin{array}{l}\text { Always that serves the } \\
\text { nation }\end{array}$ \\
& Frequency & and & Frequency and percentage & Frequency & and
\end{tabular}




\begin{tabular}{llll}
\hline & Percentage & & Percentage \\
Highly & $21(14.0 \%)$ & $18(12.0 \%)$ & $17(11.4 \%)$ \\
Satisfactory & & & $57(38.2 \%)$ \\
Satisfactory & $68(45.3 \%)$ & $83(55.3 \%)$ & $64(42.7 \%)$ \\
Unsatisfactory & $48(32.0 \%)$ & $35(23.3 \%)$ & $11(7.3 \%)$ \\
Highly & $13(8.7 \%)$ & $13(8.7 \%)$ & $149(100 \%)$ \\
unsatisfactory & & & \\
TOTAL & $150(100 \%)$ & $150(100 \%)$ & \\
\hline
\end{tabular}

\subsubsection{Interest in Work Community Cooperation}

The majority of the respondents $(59.3 \%)$ have indicated that NUL graduates show interest in work community cooperation and also have commitment to work with surrounding community on issues and problems. The fact that NUL have interest with community cooperation is an indication of gaining an independent mind and positive attitudes, probably from the classroom instruction. It appears that the classroom instruction instilled some measure of change in the graduates to perform better at work. On the contrary, a statement can be made that NUL has failed to prepare students to meet the challenges in their workplaces. This is clearly visible through a

$(40.7 \%)$ respondents that have specified its negativity as far as interest in community cooperation is concerned. It is understandable, therefore, that some programmes do not emphasise in their learning knowledge and skills in community engagement and involvement. Alternatively, it could be said that the non - participation in community cooperation reveals that the type of attitudes that individual graduates have, do not assist him/ her to work with the community.

\subsubsection{Are NUL Graduates Aware of the Changing National Needs and Shrinking National Resources?}

Shrinking resources centralise around national needs and references. As a result, it is assumed that teaching might have been effective in helping graduates with information and knowledge on changing national needs and shrinking resources. On the other hand, most graduates might have been keen to learn the details on the national needs and resources. That is why the issue was rated highly satisfactory and satisfactory by $(67.3 \%)$ respondents. However, (32\%) were still dissatisfied and highly dissatisfied on the way graduates do not have a close look at the national needs and shrinking resources. This means that the classroom situation has failed to give an impact on the graduates to realise the need of understanding the country's economic status.

\subsubsection{Always Active in the Work that Serves the Nation?}

Again, there was no clear indication of whether or not NUL graduates are always active in the work that serves the nation. This is Close to half of the respondents $(49.6 \%)$ who indicated satisfied and strongly satisfied with the way NUL graduates activities that serve the nation. While the other half (50\%) indicated that they were not at all satisfied with inappropriate handling of activities towards serving the nation. This is the only category that shows a significant percentage of negative response. In a case where half of the respondents are not satisfied with the way graduates operate at the workplace means that a lot has to be done in relation to educating all those who are going for employment to improve their actions specifically those who would definitely work with the people. This could suggest that they should participate in community engagements, and be exposed to the variety of work related issues, such as a new course that connects the university and the world of work.

\section{Discussion}

The analysis in this study gives insights regarding the status of the NUL programmes as far as preparing students for social responsibility is concerned. On one hand, the analysis shows that there are a number of positive responses attributable to NUL programmes in contributing to social responsibility. The positive outcomes are realized on each of the items used to inquire about social responsibility. On the other hand, the analysis indicates that the NUL programmes of study have areas of concern that warrant a closer look especially with community engagements. The discussion on the analysis follows in the next paragraphs and will be related with the research questions:

As previously indicated, the results of the study seem to support NUL programmes on administrative issues such as graduates desire to achieve, effective communication, willingness to learn and continue learning, respect for management and taking orders, use of theory into practice, and attainment of service learning. All the above mentioned items have scores rated over $(70 \%)$ on agree and strongly agree combined (see Table 1 and 2 ). This 
shows that the NUL programmes in them have concepts that are geared towards helping the graduates to be accommodated in the world of work and job market.

Although the employers rated all the items on administrative issues high, the most popular and positive items are willingness to learn and continue learning, readiness for service and use of theory into practice. But, the same employers seem to be dissatisfied with NUL programmes that still fail to prepare some of the graduates for the world of work. This is evidenced in their ratings of some of the items of around (30\%) on disagree and strongly disagree combined (See Table 1 and 2). This means that the NUL still has to refine programmes that will be suitable for moulding graduates for what they are expected to do. With this type of rating, it means that some graduates still lack knowledge and confidence to act appropriately at the workplace. Certain, without the sound understanding of the workplace, it creates serious doubts about the effectiveness of NUL programmes.

The results of the study on community engagements also seem to support NUL programmes. The ratings are all above $(+50 \%)$ on community engagements such as participation in community projects, graduates relationship with the members of the community, graduate volunteer activities among the community, graduates interest in the community work and cooperation, awareness of institutional needs and sharing resources. But the item on graduates always active in the work that serves the nation has been scored closely equal (49.6\%) on satisfied and highly satisfied with $(50 \%)$ on dissatisfied and highly dissatisfied. It gives the idea that some employers are dissatisfied with the way the programmes prepare the students on the desire to serve the nation. It suggests that students in their training be made to participate in community engagements and exposed to the variety of work related issues. Alternatively, a new course that connects the University and the world of work would be beneficial to the institution.

\section{Conclusion}

This is an evaluation study. The goal of the study was to seek social responsibility initiatives in the NUL programmes. Data was sought on two research steams namely; administrative and community engagements issues. There are valuable insights depicted from the responses that indicate the nature of integration of social responsibility in the NUL programmes. As it seems, graduates have been equipped with knowledge and skills that fit the nature of the workplace. This is indicative of the employers who rated all the subsidiary items on the administrative issues at the workplace very high $(+70 \%)$ on agree and strongly agree combined on issues of desire to achieve, effective communication, willingness to learn and continue learning, respect for management and taking orders, use of theory into practice, and attainment of service learning.

The frequency counts analysis converted into percentages reveals positive responses to the following items relating to community engagements: participation in community projects, relationship with members of the community, volunteer activities among the community, interest in work community cooperation and awareness of the institutional needs and shrinking national resources. These entire subsidiary items mentioned above, have scored higher than $(50 \%)$ on satisfactory and highly satisfactory combined. The exception is on the item; readiness to serve the nation that has scored less than $(50 \%)$ on satisfactory and highly satisfactory.

In summary, as it seems, the NUL in its strategic planning has important issues and methods that allow the achievement of social responsibility activities. It means that the university has echoed its vision, mission, values, and organisational structure with social responsibility initiatives because most employers seem positively satisfied about the provision of knowledge and skills. However, the University still carries a lion's share of blame regarding those graduates that are identified as incompetent who could neither act appropriately at the workplace nor in community engagements. Probably, the NUL has to refine its programmes to accommodate every individual and promote responsible citizens who could fruitfully become involved at the workplace, local community and the world at large.

\section{References}

Ayaya (1997). Multi-variable analysis of academic success. Factors among accounting and management students at the National University of Lesotho. BOLESWA Educational Research Journal, (14), 1-5.

Bokhari, A. A. H. (2017). Universities social responsibility and sustainable development: A conceptual framework. SSRG International Journal of Economic and Management Studies, 4(12), 8-16. https://doi.org/10.14445/23939125/IJEMS-V4I12P102

Clark, B. R. (2004). Sustaining change in universities - continuities in case studies and concepts. Society for research into Higher Education and Open University Press.

Dahan, G., \& Senol, I. (2012). Corporate social responsibility in higher education institutions: Instabul Bilgi University case. American Journal of Contemporary Research, 2(3), 95-103. 
Favish, I. (2005). Portraits of practice: Social responsiveness in teaching and research at the University of Cape Town. https://doi.org/10.5130/ijcre.v2i0.1159

Gruiffe', L., \& Ratto, S. (2014). A new paradigm in higher education: University social responsibility (USR). Journal of Education and Human Development, 3(1), 231-238.

Jongbloed, B., Enders, J., \& Salern, C. (2008). Higher education and its communities: Interconnections, Interdependencies and research agenda. Higher Education, 56(3), 303-324. https://doi.org/10.1007/s10734008-9128-2

Maliyamkono, T. L., Shutri, A. G. M., \& Wells, S. S. (1982). Higher Education and Development in Eastern Africa. Heinemann.

Mohamed, A. T. E. (2015). A framework for university social responsibility and sustainability: The case of South Valley University, Egypt. International Journal of Social, Behavioural, Educational, Economic, Business, and Industrial Engineering, 9(7), 2393-2402.

Sekaran, U., \& Bougie, R. (2013). Research Methods for business. Italy: John Wiley and sons Ltd.

Tong, T. M. (2017). Promoting social responsibility among students should be key to University mission in Young Universities Summit 2017: Higher Education must promote social responsibility.

UNESCO. (1995). World Declaration on higher education for twenty-first century vision and action. World Conference on higher education. UNESCO.

University of Cape Town. (2008). Social Responsiveness document. Retrieved 7/18/2008 from http://ww.uct.ac.za/about/introsocialresponses.

Watson, D. (2004). Inventory tool for higher education civic engagement. Retrieved 9/6/2019 from http://www.tufts.Edu/talloiresnetwork/downloads/inventorytoolhighered.civicengagement.pdf

Weiss, B. (2016). The rise of social responsibility in higher education in university world news. University world news. The global window on higher education. Retrieved from $\mathrm{http}: / /$ www.universityworldnews.com/article.Php?story=20160811095808959

Wigmore - Alvarez, A., \& Lozano, M. R. (2012). University Social responsibility USR in the global context: An overview of literature. Business and Professional Ethics Journal, 31(3-4), 475-498. https://doi.org/10.5840/bpej2012313/424

\section{Copyrights}

Copyright for this article is retained by the author(s), with first publication rights granted to the journal.

This is an open-access article distributed under the terms and conditions of the Creative Commons Attribution license (http://creativecommons.org/licenses/by/4.0/). 